\title{
Growth and hematology of pacu subjected to sustained swimming and fed different protein levels
}

\author{
Cleujosí da Silva Nunes ${ }^{(1)}$, Gilberto Moraes ${ }^{(1)}$, Fernando Fabrizzi( ${ }^{(1)}$, \\ Araceli Hackbarth(1) and Gustavo Alberto Arbeláez-Rojas(1)
}

\begin{abstract}
(1)Universidade Federal de São Carlos, Departamento de Genética e Evolução, Laboratório de Bioquímica Adaptativa, Campus São Carlos, Rodovia Washington Luís, Km 235 - SP-310, CEP 13565-905 São Carlos, SP, Brazil. E-mail: cleujosi@yahoo.com.br, gil@ufscar.br, ferfabrizzi@hotmail.com, arinhahack@yahoo.com.br, matamba2@yahoo.com.br
\end{abstract}

\begin{abstract}
The objective of this work was to evaluate the effect of sustained swimming and dietary protein levels on growth and hematological responses of juvenile pacu (Piaractus mesopotamicus). A completely randomized design was used in a $3 \times 2$ factorial arrangement, with three levels of dietary protein $(24,28$, and $32 \%$ crude protein), two rearing conditions (sustained swimming or motionless water), and 15 replicates. Fish were subjected to sustained swimming at the velocity of two body lengths per second ( $\left.2 \mathrm{BL} \mathrm{s}^{-1}\right)$, for 45 days. The level of dietary protein and the swimming conditions affected the performance, growth, and hematological profile of pacu. Swimming conditions influenced nutritional factors, increasing daily weight gain, specific growth rate, number of erythrocytes, mean corpuscular volume, and mean corpuscular hemoglobin. Fish under sustained swimming and fed with $24 \%$ crude protein showed better growth performance, with higher specific growth rate (4.11 \pm 0.88$)$ and higher daily weight gain $(2.19 \pm 0.47 \mathrm{~g}$ per day). Sustained swimming can increase the productive performance of pacu and simultaneously reduce dietary protein levels.
\end{abstract}

Index terms: Piaractus mesopotamicus, erythropoiesis, exercise, growth rate, weight gain.

\section{Crescimento e hematologia de pacu submetido a natação sustentada e alimentado com diferentes níveis proteicos}

\begin{abstract}
Resumo - O objetivo deste trabalho foi avaliar o efeito da natação sustentada e de níveis de proteína na dieta sobre o crescimento e a resposta hematológica de juvenis de pacu (Piaractus mesopotamicus). Utilizou-se o delineamento inteiramente casualizado, em arranjo fatorial $3 \times 2$, com três níveis de proteína na dieta $(24,28$ e 32\% de proteína bruta), duas condições de criação (natação sustentada ou água imóvel) e 15 repetições. Os peixes foram submetidos à natação sustentada na velocidade de duas vezes o comprimento corporal por segundo $\left(2 \mathrm{CC} \mathrm{s}^{-1}\right)$, por 45 dias. O nível de proteína da dieta e as condições de nado afetaram o desempenho, o crescimento e o perfil hematológico do pacu. As condições de nado influenciaram os fatores nutricionais, com aumento de ganho de peso diário, taxa de crescimento específico, número de eritrócitos, volume corpuscular médio e hemoglobina corpuscular média. Peixes sob natação sustentada e alimentados com $24 \%$ de proteína bruta apresentaram melhor desempenho de crescimento, com maior taxa de crescimento específico $(4,11 \pm 0,88)$ e maior ganho em peso diário $(2,19 \pm 0,47 \mathrm{~g}$ por dia). A natação sustentada pode aumentar o desempenho produtivo de pacus e ao mesmo tempo reduzir os níveis de proteína na dieta.
\end{abstract}

Termos para indexação: Piaractus mesopotamicus, eritropoiese, exercício, taxa de crescimento, ganho em peso.

\section{Introduction}

Pacu (Piaractus mesopotamicus) is an omnivorous fish species with high growth rates, rusticity, and easy adaptation to artificial feeding. It lives in the Paraná, Paraguay, and Uruguay Rivers (Saint-Paul, 1986), and is a relevant fish species in Brazil.

Currently, a challenge for the fish farming industry is to reduce production costs by improving culture techniques and developing more feasible and efficient diets for different species. Protein, used for promoting tissue growth and meeting energetic demands, is the most expensive diet component (Wilson, 2002). Efforts have been made towards reducing dietary protein content, especially animal protein, due to economic and environmental reasons (Tacon \& Metian, 2008). In addition, several works have reported metabolic impairments in consequence of high protein levels (Singh et al., 2006; Portz \& Furuya, 2012).

Different strategies have been proposed to decrease protein content in diets. One of them is protein sparing, in which a higher concentration of nonprotein 
sources of energy is used to meet physiological demands (Bicudo et al., 2012). Subjecting fish to exercise can lead to the protein sparing effect, make carbohydrates and lipids more efficient in meeting energetic demands, and redirect protein to an anabolic process (Arbeláez-Rojas \& Moraes, 2010; Felip et al., 2013). These adaptions result in faster growth, better feed conversion ratios, increased survival rates, and decreased aggressive behavior (Moraes et al., 2009; Hackbarth, 2010). Sustained swimming also acts on blood flow, blood capillary diameter, and heart beating frequency (Sandblom et al., 2005).

There are studies on sustained swimming and animal nutrition in tropical freshwater fish (Hackbarth, 2010; Arbeláez-Rojas et al., 2011). However, few of them have shown beneficial effects of it on fish growth and metabolism. In general, each of these variables is studied independently, but it is reasonable to assume that the association of an ideal swimming activity and a well-balanced diet will result in more satisfactory responses on fish performance than sustained swimming or diet alone. One of the recurring concerns in the commercial breeding of fish is the reduction of dietary crude protein (CP) levels, since it would reduce production costs and the undesired effects of nitrogen excretion.

The objective of this work was to evaluate the effect of sustained swimming and dietary protein levels on growth performance and on hematological responses of juvenile pacu.

\section{Materials and Methods}

The experiment was carried out from February to April 2009 at the Universidade Federal de São Carlos,

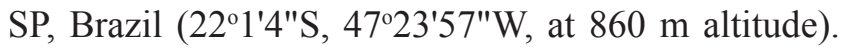
A completely randomized design was used, in a $3 \times 2$ factorial arrangement, with three levels of dietary protein $(24,28$, and $32 \% \mathrm{CP})$, two rearing conditions (sustained swimming or motionless water) and replicates. Each fish was considered as an experimental unit.

Juvenile pacu were obtained from the São Geraldo commercial fish farm, located in Sertãozinho, SP, Brazil. The fish were held in 2,000 L tanks for one month in order to be acclimatized to the experimental conditions. After this period, 90 fish were anaesthetized with $40 \mathrm{mg} \mathrm{L}^{-1}$ of eugenol (Inoue et al., 2003) and individually tagged with a microchip, implanted in the abdomen. After seven days of recovery, fish were anaesthetized, weighted $(23.9 \pm 4.7 \mathrm{~g})$, gauged $(10.6 \pm 0.77 \mathrm{~cm})$, and randomly distributed into six $200 \mathrm{~L}$ circular fiber tanks. Twenty-four hours after the biometry, the exercise protocol was performed in three tanks at the swimming velocity of two body lengths per second $\left(\mathrm{BL} \mathrm{s}^{-1}\right)$, in accordance with Moraes et al. (2009). The water velocity was generated by a NXDP4 pump (Grundfos do Brasil, Ltda., São Bernardo do Campo, SP, Brazil) as previously reported (Arbeláez-Rojas et al., 2011), and the flow was regulated every other day during the entire experimental period (45 days). Water speed was checked with a 2030 series mechanical flow meter (General Oceanics Inc., Miami, FL, USA). The following water parameters were checked daily: dissolved oxygen $\left(6.01 \pm 0.39 \mathrm{mg} \mathrm{L}^{-1}\right)$, temperature $\left(27.9 \pm 1.8^{\circ} \mathrm{C}\right)$, and ammonia $\left(0.05 \pm 0.001 \mathrm{mg} \mathrm{L}^{-1}\right)$. Besides firstbiometry, twootherbiometric evaluations weremade on the $22^{\text {nd }}$ and $45^{\text {th }}$ days of the experimental period.

Three experimental diets were formulated (Table 1), containing three levels of crude protein $(24,28$, and

Table 1. Formulation and chemical composition of the experimental diets.

\begin{tabular}{lccc}
\hline Ingredient $\left(\mathrm{g} \mathrm{kg}^{-1}\right)$ & \multicolumn{3}{c}{ Dietary protein levels $\left(\mathrm{g} \mathrm{kg}^{-1}\right)$} \\
\cline { 2 - 4 } & 240 & 280 & 320 \\
\hline Corn & 240 & 240 & 240 \\
Grinded rice & 50 & 50 & 50 \\
Soybean meal & 145 & 110 & 101 \\
Fishmeal & 260 & 330 & 410 \\
Soybean oil & 130 & 120 & 116 \\
Mineral and vitamin supplement ${ }^{(1)}$ & 20 & 20 & 20 \\
Carboxymethyl cellulose ${ }^{(2)}$ & 155 & 123 & 68 \\
Chemical composition $\left(\mathrm{g} \mathrm{kg}^{-1}\right)$ & & & \\
\hline Dry matter & 907 & 906 & 906 \\
Crude protein (CP) & 241 & 281 & 320 \\
Digestible protein & 210 & 240 & 273 \\
Total lipid (TL) & 157 & 151 & 151 \\
Carbohydrate (CHO) ${ }^{(3)}$ & 257 & 250.3 & 250.3 \\
Crude fiber & 157 & 125 & 72 \\
Mineral matter & 76 & 79 & 94 \\
Gross energy (MJ kg-1) & 16.47 & 16.76 & 17.68 \\
CHO: TL ratio & 1.63 & 1.65 & 1.65 \\
CHO: CP ratio & 1.06 & 0.89 & 0.78 \\
\hline
\end{tabular}

(1)Rovimix (Hoffmann-La Roche, Ltda., Basel, Switzerland): vitamin A, 5,000,000 IU; vitamin D3, 200,000 IU; vitamin E, 5,000 IU; vitamin K3, 1,000 mg; vitamin B1 (thiamine), 1,500 mg; vitamin B2 (riboflavin), 1,500 $\mathrm{mg}$; vitamin B6 (pyridoxine), 1,500 mg; vitamin B12, 4,000 mg; vitamin C, 15,000 mg; folic acid, $500 \mathrm{mg}$; pantothenic acid, 4,000 mg; BHT, 12.25 g; biotin, $50 \mathrm{mg}$; inositol, 1,000 mg; nicotinamide, 7,000 mg; choline, 40 $\mathrm{g}$; cobalt, $10 \mathrm{mg}$; copper, $500 \mathrm{mg}$; iron, $5,000 \mathrm{mg}$; iodine, $50 \mathrm{mg}$; manganese, 1,500 mg; selenium, $10 \mathrm{mg}$; zinc, 5,000 mg; vehicle q.s., 1,000 g. ${ }^{(2)}$ Obtained from Rhoster Indústria e Comércio, Ltda. All ingredients were grinded in a $0.5 \mathrm{~mm}$ pore sieve. ${ }^{(3)}$ Carbohydrate $=$ dry matter $-($ crude protein - total lipid + crude fiber + mineral matter). 
$32 \%$ ), one level of total lipids $(15 \%)$, and one of carbohydrate $(25 \%)$. The concentration of total lipids and carbohydrate was based on previous studies developed in the laboratory and posteriorly published by Hackbarth (2010). Fish were fed three times a day to apparent satiation, during the entire experimental period.

At the end of the experimental span, eight fish from each tank were randomly sampled, and $1 \mathrm{~mL}$ of blood was withdrawn from the caudal vein with a heparinized plastic syringe. Hematocrit (Ht), hemoglobin concentration (Hb) (Drabkin, 1948), number of red blood cells (RBC) (Lima et al., 1969), mean corpuscular volume, and mean corpuscular hemoglobin were determined. Growth performance and feed utilization were determined and calculated as follows: daily weight gain $(\mathrm{DWG}$; g per day) $=($ mean final weight - mean initial weight $/$ [ [mean initial weight $\mathrm{x}$ time (days)]; feed conversion ratio $(\mathrm{FCR})=$ feed intake $(\mathrm{g}) /$ weight gain $(\mathrm{g})$; and specific growth ratio $(\mathrm{SGR})=100 \times(\ln$ final weight $-\ln$ initial weight $) /$ time (days).

Data were analyzed by two-way analysis of variance, and means were compared by Tukey's test, at $5 \%$ probability. Data were analyzed using the SAS software, v.8 (SAS Institute, Cary, NC, USA).

\section{Results and Discussion}

Both dietary protein levels and sustained swimming affected growth performance and the hematological profile of pacu. Fish fed with 24 and 32\% CP showed the highest DWG, whereas the highest SGR was observed in fish fed with $24 \%$ CP (Table 2). This

Table 2. Growth performance of pacu (Piaractus mesopotamicus) fed with three levels of dietary protein and subjected to sustained swimming ${ }^{(1)}$.

\begin{tabular}{lccc}
\hline Factor & \multicolumn{3}{c}{ Growth performance } \\
\cline { 2 - 4 } & DWG (g per day) & FCR & SGR \\
\hline Crude protein level & & & \\
$240 \mathrm{~g} \mathrm{~kg}^{-1}$ & $2.19 \pm 0.47 \mathrm{~A}$ & $0.93 \pm 0.03$ & $4.11 \pm 0.88 \mathrm{~A}$ \\
$280 \mathrm{~g} \mathrm{~kg}^{-1}$ & $1.88 \pm 0.25 \mathrm{~B}$ & $0.92 \pm 0.04$ & $3.02 \pm 0.41 \mathrm{~B}$ \\
$320 \mathrm{~g} \mathrm{~kg}^{-1}$ & $2.02 \pm 0.46 \mathrm{~A}$ & $0.83 \pm 0.10$ & $2.83 \pm 0.65 \mathrm{~B}$ \\
\hline Rearing condition & & & \\
$\quad$ Sustained swimming & $2.21 \pm 0.45 \mathrm{~A}$ & $0.99 \pm 0.09$ & $3.61 \pm 0.99 \mathrm{~A}$ \\
$\quad$ Motionless water & $1.90 \pm 0.35 \mathrm{~B}$ & $0.80 \pm 0.10$ & $3.09 \pm 0.71 \mathrm{~B}$ \\
\hline
\end{tabular}

${ }^{(1)}$ Means \pm SD followed by equal letters do not differ by Tukey's test, at $5 \%$ probability. ${ }^{(2)}$ Swimming velocity of 2 body length per second. DWG, daily weight gain; FCR, food conversion ratio; SGR, specific growth rate. indicates that the $24 \% \mathrm{CP}$ group - in which the protein anabolism was more noticeable - had a faster growth. According to several studies, the best $\mathrm{CP}$ values for pacu are between 26 and 27\% (Abimorad et al., 2007; Bicudo et al., 2009), which supports the result obtained here. Considering that lower dietary protein reflects both lower diet costs and nitrogen wasting, the diet containing $24 \% \mathrm{CP}$ is a sound alternative to feed pacu subjected to swimming at $2 \mathrm{BL} \mathrm{s}^{-1}$.

The distinct values (Table 1) of gross energy (GE) and crude fiber (CF) did not change FCR (Table 2), showing that these conditions do not interfere in food intake of exercised pacu. Although high concentration of dietary fiber reduces food intake, increasing bolus size (Montagne et al., 2003) and satiation (Hansen \& Storebakken, 2007), the fiber used as a diet component (carboxymethyl cellulose) did not affect FCR in all groups. However, diets with more than $11 \%$ of microfine cellulose reduce the growth of pacu (Rodrigues et al., 2010). It is possible that swimming attenuated the effect of high crude fiber concentration, since all fish exhibited good FCR values.

Independently of the dietary protein level, sustained swimming at $2 \mathrm{BL} \mathrm{s}^{-1}$ resulted in the best growth performance. Fish held under sustained swimming presented higher DWG and SGR (Table 2), probably as consequence of a more efficient mobilization, due to the exercise, of carbohydrates and lipids, in order to meet energetic demand. At the same time, exercise could have redirected protein to anabolic pathways. Similar results were reported for matrinxã (Brycon amazonicus) kept under sustained swimming for 72 days at $1 \mathrm{BL} \mathrm{s}^{-1}$. An improvement in FCR was observed, increasing growth and leading to greater weight gain (Hackbarth \& Moraes, 2006). In another work with the same species, with sustained swimming span extended to 90 days at $1-1.5 \mathrm{BL} \mathrm{s}^{-1}$, Arbeláez-Rojas \& Moraes (2010) observed a 20\% increase in growth and weight gain. Sustained swimming at velocities between 1 and $2 \mathrm{BL} \mathrm{s}^{-1}$ improves pacu mean weight, mean length, FCR, and protein efficiency ratio, especially at $2 \mathrm{BL} \mathrm{s}^{-1}$ (Hackbarth, 2010). Therefore, sustained swimming can be considered a stimulator of growth and of carbohydrate and lipid utilization in order to meet the increased metabolic expenditures (Moraes et al., 2009).

Other studies on sustained swimming have shown that it stimulates fish growth and weight gain, bringing 
advantages over the usually stationary system (Hackbarth \& Moraes, 2006; Arbeláez-Rojas \& Moraes, 2010; Arbeláez-Rojas et al., 2011). Moreover, fish farming under moderate water streams facilitates food-pellet intake and improves their distribution, which reduces the potential aggressiveness of fish when searching for food. Therefore, moderate-velocity water have shown several advantages over lentic waters (Arbeláez-Rojas et al., 2011).

The dietary protein levels (Table 3 ) can explain the alterations observed in $\mathrm{RBC}$ (in the $32 \% \mathrm{CP}$ group), in $\mathrm{Ht}$ and $\mathrm{MCV}$ (24 an 28\% CP groups), and in $\mathrm{MCH}$ (24\% CP group). Hematological alterations reflect the improvement of nutrient and oxygen transport, and of higher tissue oxygen uptake. Changes in MCV should be related to osmoregulatory status, cardiac dynamics, and blood flow, which change due to exercise. Matrinxã subjected to sustained swimming at $1 \mathrm{BL} \mathrm{s}^{-1}$ did not show alteration in hemoglobin, MCV, and MCHC levels (Hackbarth \& Moraes, 2006); whereas under sustained swimming at $1.5 \mathrm{BL} \mathrm{s}^{-1}$, Arbeláez-Rojas \& Moraes (2010) reported increased contents of hemoglobin, $\mathrm{Ht}$, and $\mathrm{RBC}$. In both works, the authors concluded that exercise increases metabolic demand, which, in turn, caused a series of hematological adaptions. Hackbarth (2010) reported increased levels of hematocrit, hemoglobin, VCM, and $\mathrm{HCM}$ in pacu exposed to $2 \mathrm{BL} \mathrm{s}^{-1}$ and attributed these alterations to exercise.

In the present study, $\mathrm{RBC}$ and $\mathrm{MCH}$ parameters were also altered by exercise (Table 3). The increased RBC observed in fish fed with $32 \% \mathrm{CP}$ may be explained by one of the following factors: $1, \mathrm{RBC}$ release into the blood stream from a spleen contraction, where a large number of these cells is stored; or 2, a higher $\mathrm{RBC}$ value followed by lower $\mathrm{Ht}, \mathrm{MCV}$, and $\mathrm{MCH}$, suggesting the presence of young erythrocytes from erythropoiesis. Studies with other species have also shown interference of $\mathrm{CP}$ on hematological variables. Camargo et al. (2005), for example, observed increased $\mathrm{RBC}, \mathrm{Hb}$ concentration, and $\mathrm{Ht}$ values in silver catfish (Rhamdia quelen) fed with 50\% CP. Abdel-Tawwab et al. (2010) also found changes in $\mathrm{RBC}, \mathrm{Hb}$, and $\mathrm{Ht}$ in response to dietary protein, when studying Nile tilapia (Oreochromis niloticus). However, specific mechanisms in fish involving erythropoiesis and dietary CP still remain to be elucidated.

The lower number of erythrocytes observed in fish under sustained swimming was probably offset by the larger volume of these cells. The number of RBC decreased about $13.8 \%$, but an equivalent reduction of hematocrit was not observed. This means that the erythrocyte volume swelled, which is typical of the enhanced oxygen demand provided by aerobic exercise. The increases in MCV and $\mathrm{MCH}$ resulted from metabolic adaption to deal with higher oxygen uptake and transport. The same responses were observed in matrinxã subjected to intermittent sustained swimming at $12 \times 12$ hours vs. rest (Fabrizzi et al., 2013). It is reasonable to infer that the hematological responses found in the present study may be typical of the species, and that they may also depend on external factors, such as swimming speed and exercise type (Hackbarth \& Moraes, 2006; Moraes et al., 2009; Arbeláez-Rojas \& Moraes, 2010; Fabrizzi et al., 2013). Furthermore, the observed hematological changes may indicate metabolic adaption in order to meet oxygen demand.

Pacu fed with $24 \%$ CP and subjected to sustained swimming reached higher DWG and SGR than non-exercised fish (Table 4). Sustained swimming stimulated the use of other nutrients for energy demands, redirecting protein to an anabolic process. According to

Table 3. Hematological parameters of pacu (Piaractus mesopotamicus) subjected to sustained swimming and fed three levels of crude $\operatorname{protein}^{(1)}$.

\begin{tabular}{|c|c|c|c|c|c|}
\hline \multirow[t]{2}{*}{ Factor } & \multicolumn{5}{|c|}{ Hematological parameter } \\
\hline & $\mathrm{RBC}\left(10^{6} \mathrm{~mm}^{-3}\right)$ & Hematocrit (\%) & Hemoglobin $(\mathrm{g} \%)$ & $\operatorname{MCV}\left(\mu^{3}\right)$ & $\mathrm{MCH}(\mu \mathrm{g})$ \\
\hline \multicolumn{6}{|l|}{ Crude protein level } \\
\hline $240 \mathrm{~g} \mathrm{~kg}^{-1}$ & $1.68 \pm 0.33 \mathrm{~B}$ & $31.15 \pm 2.58 \mathrm{AB}$ & $7.95 \pm 0.80$ & $191.04 \pm 37.08 \mathrm{~A}$ & $48.43 \pm 8.66 \mathrm{~A}$ \\
\hline $280 \mathrm{~g} \mathrm{~kg}^{-1}$ & $1.90 \pm 0.28 \mathrm{~B}$ & $31.34 \pm 1.19 \mathrm{~A}$ & $8.31 \pm 0.42$ & $168.15 \pm 22.00 \mathrm{~A}$ & $44.69 \pm 6.70 \mathrm{AB}$ \\
\hline $320 \mathrm{~g} \mathrm{~kg}^{-1}$ & $2.28 \pm 0.47 \mathrm{~A}$ & $29.15 \pm 3.22 \mathrm{~B}$ & $8.74 \pm 1.33$ & $134.30 \pm 39.49 \mathrm{~B}$ & $39.68 \pm 9.07 \mathrm{~B}$ \\
\hline \multicolumn{6}{|l|}{ Rearing condition } \\
\hline Sustained swimming ${ }^{(2)}$ & $1.81 \pm 0.41 \mathrm{~B}$ & $30.81 \pm 2.27$ & $8.48 \pm 1.10$ & $178.31 \pm 39.26 \mathrm{~A}$ & $48.29 \pm 7.99 \mathrm{~A}$ \\
\hline Motionless water & $2.10 \pm 0.42 \mathrm{~A}$ & $30.29 \pm 2.92$ & $8.19 \pm 0.79$ & $150.69 \pm 36.60 \mathrm{~B}$ & $40.25 \pm 7.81 \mathrm{~B}$ \\
\hline
\end{tabular}

${ }^{(1)}$ Means \pm SD followed by equal letters do not differ by Tukey's test, at $5 \%$ probability. ${ }^{(2)}$ Swimming velocity of 2 body length per second. RBC, red blood cell; MCV, mean corpuscular volume; $\mathrm{MCH}$, mean corpuscular hemoglobin. 
Richards et al. (2002), sustained swimming accelerates body growth through stimulation of protein synthesis and hypertrophy of muscle fibers. Therefore, in pacu exercised at $2 \mathrm{BL} \mathrm{s}^{-1}, 24 \% \mathrm{CP}$ is enough to promote higher growth values. Considering that the present study was conducted with specimens of the same brood, it may be inferred that the treatments are the main responsible for the observed effects. Similar responses have been reported in matrinxã fed with $28 \% \mathrm{CP}$ and subjected to sustained swimming (Arbeláez-Rojas et al., 2011).

Sustained swimming and lower CP dietary levels in pacu interacted through the blood parameters $\mathrm{RBC}$, $\mathrm{MCV}$, and MCH (Table 4). Fish fed with $24 \% \mathrm{CP}$ under sustained swimming showed reduction of RBC when compared with sedentary ones. However, an increase of MCV and MCH was observed in fish fed with 24 and $28 \% \mathrm{CP}$ under sustained swimming. Low dietary protein levels associated with sustained swimming seem to reduce $\mathrm{RBC}$ and to increase erythrocyte volume and hemoglobin concentration. There is an inverse correlation between cell size and fish ability to endure sustained swimming. Therefore, pacu adapted to the sustained swimming condition showed reduced erythrocyte size and produced new RBC to meet the physiological demands.

Higher growth rates, ideal FCR, and protein sparing effect make sustained swimming at $2 \mathrm{BL} \mathrm{s}^{-1}$ an excellent support for pacu farming.

Table 4. Interaction between sustained swimming and dietary protein in pacu (Piaractus mesopotamicus) for growth and hematological parameters ${ }^{(1)}$.

\begin{tabular}{|c|c|c|c|}
\hline \multirow[t]{2}{*}{ Rearing condition } & \multicolumn{3}{|c|}{ Dietary protein levels $\left(\mathrm{g} \mathrm{kg}^{-1}\right)$} \\
\hline & 240 & 280 & 320 \\
\hline & \multicolumn{3}{|c|}{ Daily weight gain (g per day) } \\
\hline Sustained swimming ${ }^{(2)}$ & $2.47 \pm 0.45 \mathrm{~A}$ & $1.90 \pm 0.17$ & $2.19 \pm 0.45$ \\
\hline \multirow[t]{2}{*}{ Motionless water } & $1.97 \pm 0.37 \mathrm{~B}$ & $1.86 \pm 0.29$ & $1.87 \pm 0.42$ \\
\hline & \multicolumn{3}{|c|}{ Specific growth rate } \\
\hline Sustained swimming & $3.73 \pm 0.45$ & $3.06 \pm 0.27$ & $3.07 \pm 0.64$ \\
\hline \multirow[t]{2}{*}{ Motionless water } & $3.18 \pm 0.42$ & $3.00 \pm 0.47$ & $2.62 \pm 0.59$ \\
\hline & \multicolumn{3}{|c|}{ Red blood cells $\left(10^{6} \mathrm{~mm}^{-3}\right)$} \\
\hline Sustained swimming & $1.51 \pm 0.25 \mathrm{~B}$ & $1.74 \pm 0.22 \mathrm{~B}$ & $2.18 \pm 0.47$ \\
\hline \multirow[t]{2}{*}{ Motionless water } & $1.86 \pm 0.32 \mathrm{~A}$ & $2.06 \pm 0.27 \mathrm{~A}$ & $2.38 \pm 0.49$ \\
\hline & \multicolumn{3}{|c|}{ Mean corpuscular volume $\left(\mu^{3}\right)$} \\
\hline Sustained swimming & $213.22 \pm 25.34 \mathrm{~A}$ & $179.40 \pm 20.4 \mathrm{~A}$ & $142.33 \pm 37.12$ \\
\hline Motionless water & $168.87 \pm 43.35 \mathrm{~B}$ & $156.90 \pm 18.4 \mathrm{~B}$ & $126.27 \pm 42.22$ \\
\hline
\end{tabular}

${ }^{(1)}$ Means \pm SD followed by equal letters do not differ by Tukey's test, at $5 \%$ probability. ${ }^{(2)}$ Swimming velocity of 2 body length per second.

\section{Conclusions}

1. Sustained swimming and lower crude protein levels improve growth performance of juvenile pacu (Piaractus mesopotamicus) and favor hematologic adaptations in order to maintain the biological demands from the exercise.

2. It is possible to reduce the level of dietary protein in pacu farming if the fish are kept under sustained swimming at two body length per second.

\section{Acknowledgements}

To Conselho Nacional de Desenvolvimento Científico e Tecnológico (CNPq), for financial support; and to Antônio Aparecido da Silva, for technical support.

\section{References}

ABDEL-TAWWAB, M.; AHMAD, M.H.; KHATTAB, Y.A.E.; SHALABY, A.M.E. Effect of dietary protein level, initial body weight, and their interaction on the growth, feed utilization, and physiological alterations of Nile tilapia, Oreochromis niloticus (L.). Aquaculture, v.298, p.267-274, 2010. DOI: 10.1016/j. aquaculture.2009.10.027.

ABIMORAD, E.G.; CARNEIRO, D.J.; URBINATI, E.C. Growth and metabolism of pacu (Piaractus mesopotamicus Holmberg 1887) juveniles fed diets containing different protein, lipid and carbohydrate levels. Aquaculture Research, v.38, p.36-44, 2007. DOI: 10.1111/j.1365-2109.2006.01621.x.

ARBELÁEZ-ROJAS, G.; MORAES, G. Optimization of sustaining swimming speed of matrinxã Brycon amazonicus: performance and adaptive aspects. Scientia Agricola, v.67, p.253-258, 2010. DOI: $10.1590 / \mathrm{S} 0103-90162010000300001$.

ARBELÁEZ-ROJAS, G.A.; INOUE, L.A.K.A.; MORAES, G. Atividade proteolítica e crescimento de matrinxã em natação sustentada e alimentado com dois níveis de proteína. Pesquisa Agropecuária Brasileira, v.46, p.1521-1529, 2011. DOI: 10.1590/ S0100-204X2011001100014.

BICUDO, A.J. de A.; ABIMORAD, E.G.; CARNEIRO, D.J. Exigências nutricionais e alimentação do pacu. In: FRACALOSSI, D.M.; CYRINO, J.E.P. (Ed.). Nutriaqua: nutrição e alimentação de espécies de interesse para aquicultura brasileira. Florianópolis: Sociedade Brasileira de Aquicultura e Biologia Aquática, 2012. p.217-229.

BICUDO, A.J. de A.; SADO, R.Y.; CYRINO, J.E.P. Growth and haematology of pacu, Piaractus mesopotamicus, fed diets with varying protein to energy ratio. Aquaculture Research, v.40, p.486-495, 2009. DOI: 10.1111/j.1365-2109.2008.02120.x.

CAMARGO, S.O.; POUEY, J.L.; MARTINS, C. Parâmetros eritrocitários do jundiá (Rhamdia quelen) submetido à dieta com diferentes níveis de proteína. Ciência Rural, v.35, p.1406-1411, 2005. DOI: $10.1590 /$ S0103-84782005000600028. 
DRABKIN, D.L. The standardization of hemoglobin measurement. The American Journal of the Medical Sciences, v.215, p.110-111, 1948.

FABRIZZI, F.; MORAES, G.; HACKBARTH, A.; ALMEIDA, L.C. de; ARBELÁEZ-ROJAS, G.; NUNES, C. da S. Intermittent sustained swimming in 'matrinxã' Brycon amazonicus (Bryconidae: Bryconinae): hematological and metabolic responses. Neotropical Ichthyology, v.11, p.425-432, 2013. DOI: 10.1590/ S1679-62252013000200013.

FELIP, O.; BLASCO, J.; IBARZ, A.; MARTIN-PEREZ, M.; FERNÁNDEZ-BORRÀS, J. Beneficial effects of sustained activity on the use of dietary protein and carbohydrate traced with stable isotopes $15 \mathrm{~N}$ and $13 \mathrm{C}$ in gilthead sea bream (Sparus aurata). Journal of Comparative Physiology B, v.183, p.223-234, 2013. DOI: $10.1007 / \mathrm{s} 00360-012-0703-6$.

HACKBARTH, A. Exercício aeróbico e suas implicações no crescimento e metabolismo de pacu (Piaractus mesopotamicus). 2010. 112p. Tese (Doutorado) - Universidade Federal de São Carlos, São Carlos.

HACKBARTH, A.; MORAES, G. Biochemical responses of matrinxã Brycon cephalus (Gunther, 1869) after sustained swimming. Aquaculture Research, v.37, p.1070-1078, 2006. DOI: $10.1111 /$ j.1365-2109.2006.01530.x.

HANSEN, J.O.; STOREBAKKEN, T. Effects of dietary cellulose level on pellet quality and nutrient digestibilities in rainbow trout (Oncorhynchus mykiss). Aquaculture, v.272, p.458-465, 2007. DOI: 10.1016/j.aquaculture.2007.09.005.

INOUE, L.A.K.A.; SANTOS NETO, C. dos; MORAES, G. Clove oil as anesthetic for juveniles of matrinxã, Brycon cephalus (Gunther, 1869). Ciência Rural, v.33, p.943-947, 2003. DOI: $10.1590 / \mathrm{S} 0103-84782003000500023$.

LIMA, A.O.; SOARES, J.B.; GREGO, J.B.; GALIZZI, J.; CANCADO, J.R. Métodos de laboratório aplicados à clínica. 4.ed. Rio de Janeiro: Guanabara Koogan, 1969. 653p.

MONTAGNE, L.; PLUSKE, J.R.; HAMPSON, D.J. A review of interactions between dietary fibre and the intestinal mucosa, and their consequences on digestive health in young non-ruminant animals. Animal Feed Science and Technology, v.108, p.95-117, 2003. DOI: 10.1016/S0377-8401(03)00163-9.
MORAES, G.; HACKBARTH, A.; ARBELÁEZ-ROJAS, G.A.; FABRIZZI, F.; NUNES, C.S. Adaptações bioquímicas à natação sustentada em peixes com alto potencial para piscicultura. In: TAVARES-DIAS, M. (Org.). Manejo e sanidade de peixes em cultivo. Macapá: Embrapa Amapá, 2009. p.269-294.

PORTZ, L.; FURUYA, W.M. Energia, proteína e aminoácidos. In: FRACALOSSI, D.M.; CYRINO, J.E.P. (Ed.). Nutriaqua: nutrição e alimentação de espécies de interesse para aquicultura brasileira. Florianópolis: Sociedade Brasileira de Aquicultura e Biologia Aquática, 2012. p.65-77.

RICHARDS, J.G.; MERCADO, A.J.; CLAYTON, C.A.; HEIGENHAUSER, G.J.F.; WOOD, C.M. Substrate utilization during graded aerobic exercise in rainbow trout. Journal of Experimental Biology, v.205, p.2067-2077, 2002.

RODRIGUES, L.A.; FERNANDES, J.B.K.; FABREGAT, T. El H.P.; SAKOMURA, N.K. Desempenho produtivo, composição corporal e parâmetros fisiológicos de pacu alimentado com níveis crescentes de fibra. Pesquisa Agropecuária Brasileira, v.45, p.897-902, 2010. DOI: 10.1590/S0100-204X2010000800016.

SAINT-PAUL, U. Potential for aquaculture of South American freshwater fishes: a review. Aquaculture, v.54, p.205-240, 1986. DOI: 10.1016/0044-8486(86)90329-7.

SANDBLOM, E.A.P.; FARRELL, A.P.; ALTIMIRAS, J.; AXELSSON, M.; CLAIREAUX, G. Cardiac preload and venous return in swimming sea bass (Dicentrarchus labrax L.). The Journal of Experimental Biology, v.208, p.1927-1935, 2005. DOI: $10.1242 /$ jeb.01606.

SINGH, P.K.; GAUR, S.R.; CHARI, M.S. Effect of varying protein levels on the growth of Indian Major Carp Rohu, Labeo rohita (Hamilton). International Journal of Zoological Research, v.2, p.186-191, 2006. DOI: 10.3923/ijzr.2006.186.191.

TACON, A.G.J.; METIAN, M. Global overview on the use of fish meal and fish oil in industrially compounded aquafeeds: trends and future prospects. Aquaculture, v.285, p.146-158, 2008. DOI: 10.1016/j.aquaculture.2008.08.015.

WILSON, R.P. Amino acids and proteins. In: HALVER, J.E.; HARDY, R.W. (Ed.). Fish nutrition. $3^{\text {rd }}$ ed. San Diego: Academic Press, 2002. p.144-175.

Received on November 17, 2012 and accepted on May 27, 2013

Pesq. agropec. bras., Brasília, v.48, n.6, p.645-650, jun. 2013

DOI: $10.1590 / \mathrm{S} 0100-204 X 2013000600010$ 